\title{
NILAI PASAR, ASET TETAP, PROFITABILITAS, STRUKTUR MODAL DAN NILAI PERUSAHAAN PADA PERUSAHAAN YANG MELAKUKAN IPO DI TAHUN 2013
}

\author{
Matilda \\ Program Studi Magister Manajemen Universitas Tarumanagara \\ hillovy@gmail.com
}

Masuk : 05-12-2017, revisi : 20-12-2017 diterima untuk diterbitkan : 20-12-2017

\begin{abstract}
This research aims to find out financial performance of firms that conduct an IPO of shares in the year of 2013 which are listed in the Indonesian Capital Market (Bursa Efek Indonesia) for observation period 2013 until 2016, using Tobin's Q model. To get the value of Tobin's Q, data are collected form internet, such as financial statement and closing stock price. Companies with highest Q value (overvalued condition) illustrates that the company has high investment growth. Which variations are influenced by variations of free variables such as market value, tangibility, profitability, and capital structure. The specific uniqueness is emperical data are generally applied for IPO-firms. Because IPO is a phenomenon of the early phase of growth. This research conducted by using Eviews 8. Model 1 uses random effect model. Model 2 uses fixed effect model. The conclusion of this research is that market value, tangibility dan profitability have significant influence for capital structure. Futhermore, firm value would be more fit with capital structure as compared to profitability. Because profitability of firms that conduct an IPO of share is negative.
\end{abstract}

Keywords: Firm Value, Capital Structure, Market Value, Tangibility, Profitability.

\section{PENDAHULUAN \\ Latar Belakang}

Menurut Sutrisno (2016), keputusan pendanaan adalah keputusan untuk memilih sumber pendanaan, baik jenis atau jumlah, untuk membentuk struktur modal. Manajer keuangan dituntut untuk mencari sumber pendanaan dengan biaya murah dan dengan komposisi optimal, yaitu: struktur modal yang menciptakan biaya modal terendah.

Teori struktur modal menyatakan kebijakan pembiayaan mengenai struktur modal ditujukan untuk mengoptimalkan nilai perusahaan. Pemegang saham mungkin mengharapkan perusahaan untuk mencapai nilai optimalnya pada kondisi utang optimal. Namun kenyataannya, bila nilai utang terlampau optimal atau melebihi biaya kebangkrutan maka utang akan berdampak negatif terhadap nilai perusahaan (Hermuningsih, 2013).

Dalam penelitian yang dilakukan oleh Baker dan Wurgler (2002), dijelaskan dengan menggunakan regresi leverage yang mengendalikan market-to-book saat ini, membuat ratarata tertimbang untuk diambil variasi deret waktu dalam perusahaan (time series). Faktanya bahwa variasi ini membantu menjelaskan hasil struktur modal berimplikasi pada fluktuasi temporer di valuasi pasar dapat menyebabkan perubahan permanen pada struktur modal. Bertentangan dengan teori Baker dan Wurgler (2002), Hovakimian (2006) menjelaskan jika kebutuhan pembiayaan bersih tidak berkolerasi sempurna dengan kondisi pasar ekuitas dan perusahaan hanya meningkatkan ekuitas ketika rasio market-to-book tinggi maka perusahaan yang membutuhkan dana eksternal cenderung akan menaikkan utang ketika rasio market-tobook rendah. Demikian pula, jika perusahaan membeli kembali ekuitas saat rasio market-tobook rendah maka perusahaan dengan kelebihan uang tunai cenderung akan tidak berutang saat rasio market-to-book tinggi.

Asset tangibility menurut Hunafa dan Nugroho (2014), merupakan aset tetap perusahaan seperti gedung dan tanah dapat dijadikan jaminan dimana sesuai dengan teori trade-off, 
semakin besar proporsi aset tetap dalam neraca, semakin besar kemauan pemberi pinjaman untuk memberikan pinjaman, maka seiring dengan porsi leverage juga akan meningkat. Namun menurut Setyawan dan Frensidy (2012), pada saat IPO aset tetap tidak akan dijadikan jaminan untuk pembiayaan utang. Karena akan ada peningkatan aset tetap dengan penyertaan modal pemegang saham baru. Perusahaan yang memiliki aktiva berwujud yang cukup besar, cenderung menggunakan utang dalam proporsi yang lebih besar dibandingkan dengan perusahaan dengan aktiva tak berwujud besar meskipun yang terakhir ini memiliki kesempatan tumbuh lebih baik. Ini mudah dipahami karena perusahaan yang hanya memiliki goodwill namun tidak didukung oleh aktiva berwujud yang cukup, sulit untuk diprediksi prospek kinerjanya (Hermuningsih, 2013).

Pertumbuhan profitabilitas menunjukkan prospek perusahaan yang lebih baik yang ditangkap investor sebagai sinyal positif dari perusahaan yang akan mempermudah pengelolaan untuk mendapatkan modal dalam bentuk saham. Kesejahteraan pemegang saham dan nilai perusahaan biasanya diwakili pada harga saham, yang secara implisit mewakili keputusan investasi, pembiayaan, dan pengelolaan aset (Hermuningsih, 2013). Menurut Acaravci, Songul K. (2015), akan lebih menguntungkan jika perusahaan menggunakan lebih sedikit utang, ini sesuai dengan teori packing order. Perusahaan dengan keuntungan tinggi menggunakan pembiayaan internal, sementara perusahaan dengan keuntungan rendah menggunakan lebih banyak utang karena dana internal mereka tidak memadai.

Peningkatan jumlah utang dalam struktur modal suatu perusahaan menandakan bahwa perusahaan telah merasa yakin akan prospek pendapatan perusahaan di masa depan. Hal ini akan menyebabkan permintaan saham perusahaan tersebut naik dan akhirnya akan meningkatkan nilai perusahaan. Kebijakan penggunaan utang dalam strktur modal suatu perusahaan akan memberikan kesempatan perusahaan untuk berkembang (Pangulu dan Maski, 2014).

\section{Tujuan Penelitian}

Berdasarkan latar belakang yang telah diuraikan, maka tujuan dari penelitian adalah untuk mengetahui:

1. Apakah nilai pasar berpengaruh terhadap struktur modal.

2. Apakah aset tetap berpengaruh terhadap struktur modal.

3. Apakah profitabilitas berpengaruh terhadap struktur modal.

4. Apakah profitabilitas berpengaruh terhadap nilai perusahaan.

5. Apakah struktur modal berpengaruh terhadap nilai perusahaan.

6. Apakah nilai pasar, aset tetap dan profitabilitas secara simultan berpengaruh terhadap struktur modal.

7. Apakah profitabilitas dan struktur modal secara simultan berpengaruh terhadap nilai perusahaan.

\section{TELAAH KEPUSTAKAAN}

Menurut Harmono (2016), tujuan manajemen keuangan perusahaan adalah memaksimalkan nilai kekayaan pemegang saham. Nilai kekayaan dapat dilihat melalui perkembangan harga saham (common stock) perusahaan di pasar. Menurut Hermuningsih (2013), kenaikan harga saham akan meningkatkan nilai perusahaan yang secara implisit mewakili keputusan investasi, pembiayaan dan pengelolaan aset. Menurut Riyanto (1999) dalam Hermuningsih (2013), struktur modal merupakan patokan dalam menentukan nilai perusahaan, apakah kegiatan pendanaan perusahaan menggunakan modal dari investor atau dari utang. Struktur modal merupakan bagian dari struktur keuangan yang mencerminkan rasio (absolut dan relatif) antara seluruh modal eksternal (baik dalam jangka pendek maupun dalam jangka panjang) dengan jumlah keseluruhan modal.

Keuangan perusahaan adalah yang terbaik dipahami sebagai efek kumulatif dari usaha masa lalu untuk pasar. Ide dasarnya adalah bahwa manajer melihat kondisi saat ini baik di pasar 
utang maupun di pasar ekuitas. Jika manajer membutuhkan pembiayaan, maka mereka akan menggunakan pasar mana saja yang terlihat lebih menguntungkan saat ini. Jika pasar tidak terlihat menguntungkan, maka penggalangan dana dapat ditangguhkan. Atau jika sangat menguntungkan maka dana dapat dinaikkan. Yang berarti jika pasar ekuitas menguntungkan maka perusahaan akan mengeluarkan lebih banyak ekuitas. Juga berarti jika kondisi pasar utang relatif tidak menguntungkan maka perusahaan akan cenderung mengurangi penggunaan utang (Baker \& Wurgler, 2002).

Aset tetap biasanya yang dibeli melalui utang dan dianggap sebagai dukungan kreditur pada saat likuidasi perusahaan. Sebuah perusahaan dengan aset berwujud perlu memiliki aset jaminan lebih untuk membayar utang pada saat kebangkrutan, oleh karena itu akan mempunyai kemampuan untuk menarik lebih banyak utang (Alipour et. al, 2015). Perusahaan yang memiliki aset tak berwujud lebih banyak dalam bentuk biaya penelitian dan pengembangan akan lebih banyak ekuitas dan kurang utang. (Mukherjee \& Mahakud, 2012).

Pengembalian ekuitas (return on equity-ROE) adalah ukuran dari hasil yang diperoleh para pemegang saham sepanjang tahun. Karena memberikan keuntungan kepada pemegang saham adalah tujuan perusahaan, ROE menjadi ukuran hasil kinerja yang sebenarnya (Ross $e t$ al., 2009). Pertumbuhan ROE menunjukkan prospek perusahaan yang semakin baik, yang akan ditangkap oleh investor sebagai sinyal positif dari perusahaan yang selanjutnya mempermudah manajemen perusahaan untuk menarik modal dalam bentuk saham. Apabila terdapat kenaikan permintaan saham suatu perusahaan, maka secara tidak langsung akan menaikkan harga saham tersebut di pasar modal (Sari, 2005 dalam Sebastian, Alvin Kurnia,2015).

\section{METODOLOGI PENELITIAN}

Teknik pengumpulan data dalam penelitian ini dilakukan dengan studi kepustakaan dan penelitian lapangan. Teknik pengumpulan data dengan studi kepustakaan dilakukan dengan mempelajari berbagai jurnal, literatur, dan buku. Teknik penelitian lapangan dilakukan dengan mengambil data sekunder berupa laporan keuangan, yang mana data yang digunakan adalah data sekunder yang dimbil dari situs www.yahoofinance.com, situs www.idx.co.id. Kerangka konseptual dalam penelitian ini adalah sebagai berikut:

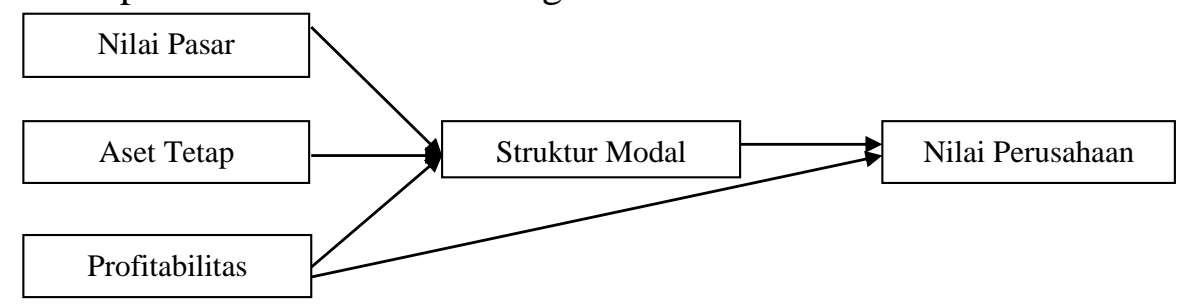

\section{Gambar 1}

Kerangka Konseptual Penelitian

Dengan model persamaan sebagai berikut:

$$
\begin{gathered}
\mathrm{CS}=\alpha_{1}+\beta_{1} \mathrm{MV}+\beta_{2} \mathrm{TANG}+\beta_{3} \mathrm{ROE}+\varepsilon_{1} \\
\mathrm{FV}=\alpha_{2}+\beta_{4} \mathrm{ROE}+\beta_{5} \mathrm{CS}+\varepsilon_{2}
\end{gathered}
$$

Obyek penelitian ini adalah nilai pasar (MV), aset tetap (TANG), profitabilitas (ROE), struktur modal (CS) dan nilai perusahaan (FV). Sedangkan subyek penelitian adalah perusahaan-perusahaan IPO yang terdaftar di Bursa Efek Indonesia.

Penelitian ini merupakan penelitian kuantitatif yang dilakukan dengan bantuan Eviews 8. Pada analisis data panel, digunakan tiga model regresi prediksi alternatif, yaitu Common Effect, Fixed Effect, dan Random Effect. Untuk menentukan model regresi yang digunakan, maka dilakukan proses pemilihan model: antara Pooled Least Square (PLS) dengan Fixed Effect Model $(\mathrm{FEM})=\mathrm{Uji}-$ Chow, dan Fixed Effect Model (FEM) dengan Random Effect Model $(\mathrm{REM})=\mathrm{Uji}-$ Hausman . 
Populasi dalam penelitian ini adalah perusahaan - perusahaan go public dari tahun 2013 sampai 2016 yang melakukan IPO di Tahun 2013 sebanyak 31 perusahaan. Sampel pada penelitian ini menggunakan metode purposive sampling dengan kriteria sebagai berikut:

\section{Tabel 1}

\section{Karakteristik Pemilihan Sampel}

\begin{tabular}{|l|l|r|}
\hline \multicolumn{1}{|c|}{ No } & \multicolumn{1}{|c|}{ Karaketeristik Sampel } & Keterangan \\
\hline 1. & Perusahaan yang melakukan IPO di tahun 2013 & 31 \\
\hline 2. & Perusahaan IPO berjenis usaha keuangan & 5 \\
\hline 3. & Perusahaan IPO yang tidak melaporkan laporan keuangan & 4 \\
\hline & selama periode penelitian 2013 - 2016 & 22 \\
\hline Jumlah Sampel yang dipakai & \\
\hline
\end{tabular}

\section{Operasionalisasi Variabel}

Nilai perusahaan diukur dengan Tobin's Q. Nilai pasar saham perusahaan (EMV) dikumpulkan dari hasil kelipatan harga saham penutupan dengan jumlah dari outstanding stock. Nilai buku ekuitas merusahaan (EMB) didapat dari total ekuitas, sedangkan D adalah nilai buku dari total utang (Hermuningsih, 2013).

$$
\mathbf{Q}=\frac{(E M V+D)}{(E M B+D)}
$$

Nilai pasar diukur dengan Market to book ratio. Rasio market to book diharapkan berpengaruh negatif dengan struktur modal (H1), dengan alasan perusahaan IPO membuat market to book akan tinggi, hal ini akan mendorong perusahaan untuk mengurangi pembiayaan utang. Proxy yang digunakan untuk nilai pasar adalah:

\section{Market Price per Share \\ MV = Book Value Per Share}

Aset tetap diukur dengan Fixed Assets Ratio. Diharapkan memiliki pengaruh negatif terhadap struktur modal (H2), karena saat IPO, aset tetap tidak akan dijadikan jaminan untuk pembiayaan utang. Karena akan ada peningkatan aset tetap dengan penyertaan modal pemegang saham baru (Setyawan \& Frensidy, 2012).

\section{TANG $=\frac{\text { Sum Plant, Property \& Equipment }}{\text { Total Assets }}$}

Profitabilitas dihitung dengan return on equity. Diharapkan memiliki pengaruh negatif terhadap struktur modal (H3) dan berpengaruh positif terhadap nilai perusahaan (H4) karena perusahaan IPO mengalami peningkatan keuntungan. Maka efek dari penggunaan utang akan mulai menurun (Setyawan \& Frensidy, 2012). Sedangkan pertumbuhan profitabilitas menunjukkan prospek perusahaan yang semakin baik, yang akan ditangkap oleh investor sebagai sinyal positif dari perusahaan (Sari, 2005 dalam Sebastian, Alvin Kurnia, 2015).

$$
\mathrm{ROE}=\frac{\text { Net Income }}{\text { Total Equity }}
$$

Struktur modal pada penelitian ini membahas tentang tingkat leverage utang perusahaan. Diharapkan memiliki pengaruh positif terhadap nilai perusahaan (H5) karena kebijakan penggunaan utang dalam struktur modal akan memberikan kesempatan perusahaan untuk berkembang sehingga dapat meningkatkan investasi yang akan mempengaruhi nilai perusahaan (Sebastian, Alvin Kurnia, 2015).

$$
\text { CS }=\frac{\text { Total Debt }}{\text { Total Assets }}
$$




\section{HASIL DAN KESIMPULAN}

Tabel 2

Hasil Uji Statistik Deskriptif

\begin{tabular}{|l|r|r|r|r|r|}
\hline & \multicolumn{1}{|c|}{$\mathrm{FV}$} & \multicolumn{1}{c|}{ CS } & \multicolumn{1}{c|}{ MV } & \multicolumn{1}{c|}{ TANG } & \multicolumn{1}{c|}{ ROE } \\
\hline Mean & 1.573028 & 0.50169 & 2.829886 & 0.610244 & 0.08848 \\
\hline Median & 1.145785 & 0.518115 & 1.327935 & 0.66226 & 0.08331 \\
\hline Maximum & 6.5681 & 0.96574 & 26.46326 & 0.95632 & 1.17918 \\
\hline Minimum & 0.50726 & 0.07146 & 0.19178 & 0.16411 & -0.7258 \\
\hline Std. Dev. & 1.178798 & 0.202274 & 4.062062 & 0.260924 & 0.199534 \\
\hline Skewness & 2.313602 & -0.271652 & 3.246097 & -0.371135 & 0.582576 \\
\hline Kurtosis & 8.364236 & 3.057013 & 15.89462 & 1.668493 & 15.82578 \\
\hline & & & & & \\
\hline Jarque-Bera & 184.0155 & 1.094241 & 764.2057 & 8.520887 & 608.1468 \\
\hline Probability & 0 & 0.578614 & 0 & 0.014116 & 0 \\
\hline & & & & & \\
\hline Sum & 138.4264 & 44.14868 & 249.03 & 53.7015 & 7.78621 \\
\hline Sum Sq. Dev. & 120.8922 & 3.559575 & 1435.53 & 5.923086 & 3.463803 \\
\hline & & & & & \\
\hline Observations & 88 & 88 & 88 & 88 & 88 \\
\hline
\end{tabular}

Dari output tabel 2 dapat diketahui jumlah sampel sebanyak 88 perusahaan dari seluruh perusahaan yang melaporkan IPO di tahun 2013.

1. Nilai perusahaan (FV) yang diukur dengan metode Tobin's Q dapat dilihat bahwa ratarata nilai perusahaan sebesar 1.573028 dan standar deviasi sebesar 1.178798. Dengan nilai strandar deviasi lebih kecil dari mean maka dapat dikatakan bahwa simpangan data pada variabel nilai perusahaan tersebar dengan baik.

2. Struktur modal (CS) perusahaan yang diukur dengan debt ratio dapat dilihat bahwa ratarata nilai struktur modalnya sebesar 0.50169 dan standar deviasi sebesar 0.202274 . Dengan nilai strandar deviasi lebih kecil dari mean maka dapat dikatakan bahwa simpangan data pada variabel struktur modal tersebar dengan baik.

3. Nilai pasar (MV) diukur dengan rasio market-to-book dapat dilihat bahwa rata-rata nilai pasanya sebesar 2.829886 dan standar deviasi sebesar 4.062062. Dengan nilai standar deviasi lebih besar dari mean menunjukkan bahwa adanya fluktuasi nilai pasar yang besar.

4. Aset tetap (TANG) diukur dengan rasio fixed assets dapat dilihat bahwa rata-rata nilai aset tetapnya sebesar 0.610244 dan standar deviasi sebesar 0.260924 . Dengan nilai standar deviasi lebih kecil dari mean maka dapat dikatakan bahwa simpangan data pada variabel aset tetap tersebar dengan baik.

5. Profitabilitas (ROE) diukur dengan rasio ROE dapat dilihat bahwa rata-rata nilai profitabilitasnya sebesar 0.08848 dan standar deviasi sebesar 0.199534. Dengan nilai standar deviasi lebih besar dari mean maka dapat dikatakan bahwa data yang digunakan dalam variabel profitabilitas mempunyai sebaran besar.

Tabel 3

Hasil Uji Hausman Model 1

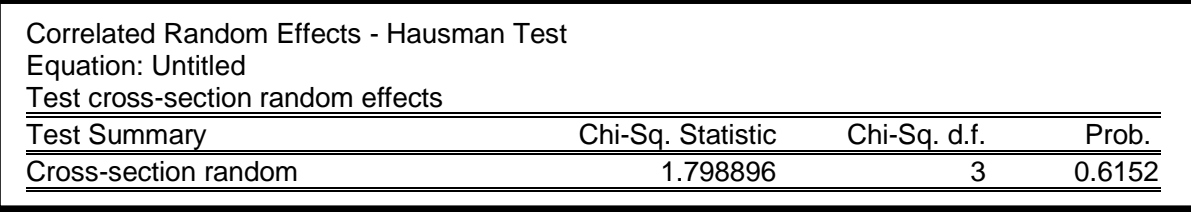

\section{Tabel 4}

Hasil Uji Hausman Model 2

Correlated Random Effects - Hausman Test

Equation: Untitled

Test cross-section random effects

\begin{tabular}{lrrr}
\hline \hline Test Summary & Chi-Sq. Statistic & Chi-Sq. d.f. & Prob. \\
\hline \hline Cross-section random & 10.374023 & 2 & 0.0056 \\
\hline \hline
\end{tabular}


Dari tabel 3 dan tabel 4 menunjukkan bahwa :

1. Persamaan pertama (Model 1) Prob. Cross-section random yang didapat sebesar 0.6152 $>0.05$ dengan tingkat signifikan $5 \%$ sehingga Random Effect Model adalah yang terbaik untuk model persamaan pertama.

2. Persamaan kedua (Model 2) Prob. Cross-section random yang didapat sebesar $0.0056<$ 0.05 dengan tingkat signifikan $5 \%$ sehingga Fixed Effect Model adalah yang terbaik untuk model persamaan kedua.

\section{Tabel 5}

\section{Hasil Uji Random Effect Model Persamaan Pertama}

Dependent Variable: CS

Method: Panel EGLS (Cross-section random effects)

Date: 11/19/17 Time: 20:08

Sample: 20132016

Periods included: 4

Cross-sections included: 22

Total panel (balanced) observations: 88

Swamy and Arora estimator of component variances

\begin{tabular}{ccccc}
\hline \hline Variable & Coefficient & Std. Error & t-Statistic & Prob. \\
\hline \hline C & 0.347659 & 0.063276 & 5.494358 & 0.0000 \\
MV & 0.011841 & 0.003597 & 3.291942 & 0.0015 \\
TANG & 0.208617 & 0.079630 & 2.619840 & 0.0104 \\
ROE & -0.076683 & 0.037453 & -2.047435 & 0.0437 \\
\hline \hline
\end{tabular}

\begin{tabular}{llll}
\hline \hline & & & \\
& Effects Specification & S.D. & Rho \\
\hline \hline Cross-section random & 0.192559 & 0.9078 \\
Idiosyncratic random & 0.061380 & 0.0922
\end{tabular}

\begin{tabular}{llll}
\hline \multicolumn{4}{l}{ Weighted Statistics } \\
\hline \hline R-squared & 0.296022 & Mean dependent var & 0.078963 \\
Adjusted R-squared & 0.270880 & S.D. dependent var & 0.071367 \\
S.E. of regression & 0.060940 & Sum squared resid & 0.311946 \\
F-statistic & 11.77398 & Durbin-Watson stat & 1.433818 \\
Prob(F-statistic) & 0.000002 & & \\
\hline
\end{tabular}

Tabel 6

Hasil Uji Fixed Effect Model Persamaan Kedua

Dependent Variable: FV

Method: Panel Least Squares

Date: 11/19/17 Time: 22:00

Sample: 20132016

Periods included: 4

Cross-sections included: 22

Total panel (balanced) observations: 88

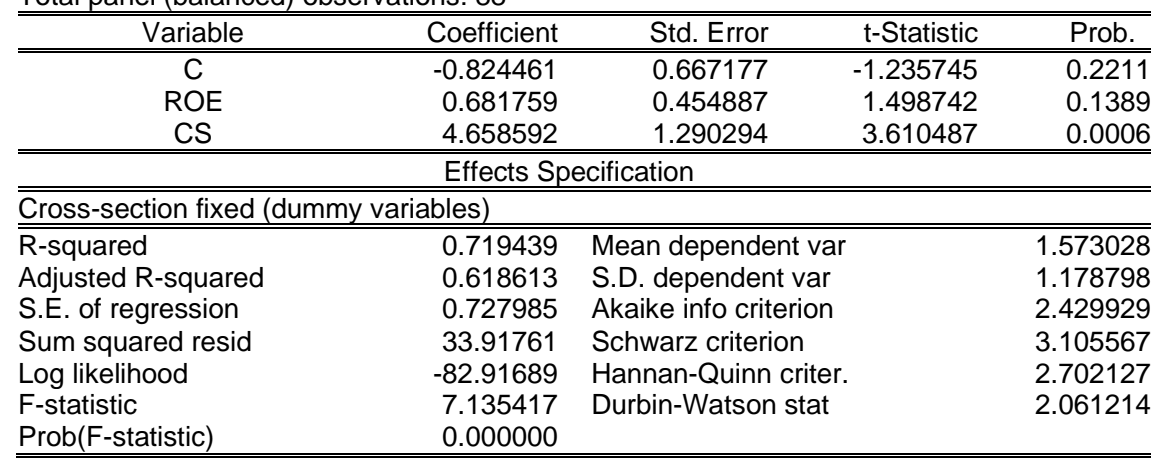



berikut:

Dari hasil uji (tabel 5 dan tabel 6) dapat disimpulkan persamaan model regresi sebagai

\section{Model $1:$ CS $=0.347659+0.011841 \mathrm{MV}+0.208617$ TANG -0.076683 ROE Model2 : FV = - $\mathbf{0 . 8 2 4 4 6 1}+\mathbf{0 . 6 8 1 7 5 9}$ ROE + 4.658592 CS}

1. Prob. variabel MV sebesar 0.0015 (Tabel 5) lebih kecil dari 0.05 dengan tingkat signifikan $5 \%$. Hasil penelitian ini menunjukkan pengaruh positif dan signifikan antara nilai pasar (MV) dan struktur modal (CS). Hasil penelitian ini memperkuat penelitian yang dilakukan oleh Mahajan dan Tartaroglu (2007), serta Baker dan Wurgler (2002). Penelitian Baker dan Wurgler (2002), menemukan bukti bahwa akumulasi dari efek market timing dapat mendorong struktur modal perusahaan. Yang berarti tingginya harga saham di pasar modal meningkatkan penggunaan utang. Selain itu juga dikarenakan sampel yang diambil dalam penelitian ini adalah perusahaan yang menyatakan IPO. Sehingga di awal akan ada peningkatan harga saham lama kelamaan akan ada penyesuaian terhadap utang.

2. Prob. variabel TANG sebesar 0.0104 (Tabel 5) lebih kecil dari 0.05 dengan tingkat signifikan $5 \%$. Hasil pengaruh positif dan signifikan antara aset tetap (TANG) dan struktur modal (CS). Hasil penelitian ini sejalan dengan penelitian yang dilakukan oleh Ramaratnam dan Jayaraman (2013). Hal ini dikarenakan dalam menggunakan sumber pendanaan dengan utang perusahaan harus memiliki jaminan pinjaman. Selain itu sumber pendanaan dengan utang juga digunakan oleh perusahaan untuk membeli aset tetap.

3. Prob. variabel ROE sebesar 0.0437 (Tabel 5) lebih kecil dari 0.05 dengan tingkat signifikan $5 \%$. Hasil penelitian ini menunjukkan pengaruh negatif dan signifikan antara profitabilitas (ROE) dan struktur modal (CS). Hasil penelitian ini memperkuat hasil temuan Ramaratnam dan Jayaraman (2013) dan Sebastian, Alvin Kurnia (2015). Hasil negatif pada penelitian ini dikarenakan penurunan jumlah laba di beberapa perusahaan. Bahkan ada beberapa perusahaan yang merugi, dapat dilihat dari olah data statistik deskriptif yang menunjukkan nilai profitabilitas sebesar -0.7258. Dikarenakan ROE yang relatif rendah maka perusahaan cenderung menggunakan dana dari pihak eksternal.

4. Prob. variabel ROE sebesar 0.1389 (Tabel 6) lebih besar dari 0.05 dengan tingkat signifikan $5 \%$. Hasil penelitian ini menunjukkan pengaruh positif dan tidak signifikan antara profitabilitas (ROE) dan nilai perusahaan (FV). Sesuai dengan penelitian Sebastian, Alvin Kurnia (2015). Yang berarti kemampuan perusahaan dalam menghasilkan laba tidak berpengaruh terhadap nilai perusahaan.

5. Prob. variabel CS sebesar 0.0006 (Tabel 6) lebih kecil dari 0.05 dengan tingkat signifikan $5 \%$. Hasil penelitian ini menunjukkan pengaruh positif dan signifikan antara struktur modal (CS) dan nilai perusahaan (FV). Hasil penelitian ini sejalan dengan penelitian yang dilakukan oleh Sebastian, Alvin Kurnia (2015), Hermuningsih (2013), dan Pangulu dan Maski (2014). Perusahaan yang sedang bertumbuh tentunya memerlukan banyak sumber dana. Peningkatan pendanaan dengan utang memberikan kesempatan perusahaan untuk berkembang. Investor percaya struktur modal menunjukkan efesiensi kinerja dan mempengaruhi nilai perusahaan.

6. Untuk mengetahui apakah semua variabel independen (MV, TANG dan ROE) dalam persamaan model 1 berpengaruh terhadap CS. Maka dilakukan Uji-F dengan hasil Prob. (F-statistic) senilai 0.000002 (Tabel 5) lebih kecil dari 0.05 dengan tingkat signifikan 5 $\%$. Yang berarti Nilai Pasar (MV), Aset Tetap (TANG), dan Profitabilitas (ROE) berpengaruh signifikan secara simultan terhadap Struktur Modal (CS). Selain itu, pengaruh semua variabel independen (ROE dan CS) dalam persamaan model 2 terhadap FV memiliki Prob. (F-statistic) senilai 0.000000 (Tabel 6) lebih kecil dari 0.05 dengan tingkat signifikan $5 \%$. Yang berarti Profitabilitas (ROE) dan Struktur Modal (CS) berpengaruh signifikan secara simultan terhadap Nilai Perusahaan (FV). 


\section{DAFTAR PUSTAKA}

Acaravci, S. K. (2015). The determinants of capital structure: Evidence from the turkish manufacturing sector. International Journal of Economics and Financial Issues, 5(1), 158-171.

Alipour, M., Mohammadi, M. F. S., \& Darakhshan, H. (2015). Determinants of capital structure: An empirical study of firm in Iran. International Journal of Law and Management, 57(1), 53-83.

Baker, M. \& Wurgler, J. (2002). Market timing and capital structure. The Journal of Finance, $57(1)$.

Harmono. (2016). Manajemen Keuangan: Berbasis Balanced Scorecard (Edisi Kelima). Jakarta: PT. Bumi Aksara.

Hermuningsih, S. (2013). Profitability, growth opportunity, capital structure and the firm value. Bulletin of Monetary, Economics and Banking.

Hovakimian, A. (2006). Are observed capital structures determined by equity market timing? Journal of Financial and Quantitative Analysis, 41(1), 221-243.

Hunafa, A. \& Nugroho, B. Y. (2014). Pengaruh market timing terhadap struktur modal perusahaan yang melakukan penawaran saham perdana (IPO) yang tercatat di BEI periode 2002-2012.

Mahajan, A. \& Tartaroglu, S. (2007). Equity market timing and capital structure: international evidence. Journal of Banking \& Finance, 32, 754-766.

Mukherjee, S. \& Mahakud, J. (2012). Historical market-to-book ratio and corporate capital structure: Evidence from India. Global Business Review, 13(2), 339-350.

Pangulu, A. L. \& Maski, G. (2014). Pengaruh profitabilitas, growth opportunity, dan struktur modal terhadap nilai perusahaan (Studi pada perusahaan perbankan yang terdaftar di bei perode 2011-2013). Jurnal Ilmiah. Malang: Fakultas Ekonomi dan Bisnis Universitas Brawijaya.

Ramaratnam, M.S. \& Jayaraman, R. (2013). Determinants of capital structure with special reference to Indian pharmaceutical sector: Panel data analysis. Journal of Commerce and Accounting Research, 2(4), 45-50.

Ross, S. A., Westerfield, R. W., \& Jordan, B. D. (2009). Pengantar Keuangan Perusahaan (Edisi Kedelapan). Jakarta: Salemba Empat.

Sebastian, A. K. (2015). Pengaruh peluang pertumbuhan perusahaan, profitabilitas, dan struktur modal terhadap nilai perusahaan (Pada sektor manufaktur di Bursa Efek Indonesia tahun 2010-2013). Tesis. Jakarta: Program Pascasarjana Universitas Tarumanagara.

Setyawan, I. R. \& Frensidy, B. (2012). Emperical Tests for Market Timing Theory of Capital Structure on Indonesian Stock Exchange. Penang, Malaysia: 14th Malaysian Finance Association Conference 2012.

Sutrisno. (2016). Capital structure determinants and their impact on firm value: Evidence from Indonesia. Economics World, 4(4), 179-186. 